\title{
PENYATUAN KALENDER ISLAM INTERNASIONAL: PERSPEKTIF SIYASAH
}

\author{
Muhammad Iqbal \\ Fakultas Syariah UIN Sumatera Utara \\ J1. Willem Iskandar Pasar V Medan Estate \\ e-mail: dr.muhammadiqbali@yahoo.com
}

\begin{abstract}
Moslems all over the world need a calendar which can be used internationally. In order to realize such a noble need, several efforts have been made by two popular approaches, namely bisab and rukyat in establishing Islamic calendar. In the context of international Islam, this trend has been followed up by efforts of uniting global Islamic calendar. This article aims at discussing advantages of uniting global Islamic calendar in terms of political issues. From the perspectives of Islamic political science (siyasab) it can be point out that the existence of global Islamic calendar will convince the world concerning with the unity and solidarity of Islamic powers. Moslems countries will arrive at shared attitudes and responses toward the development of global issues, especially those concern with Islamic political purposes.
\end{abstract}

Kata kunci: penyatuan, kalender Islam internasional, siyasah

\section{PENDAHULUAN}

$\checkmark$ acana penyatuan kalender Islam Begitu krusialnya masalah ini, di Istambul Turki telah diadakan Kongres Penyatuan Kalender Hijriyah Internasional (International Hijry Taqwim Unity Congres) pada 28-30 Mei 2016 yang lalu. Peserta yang hadir berasal dari lebih 50 negara. Indonesia diwakili oleh Prof. Syamsul Anwar (dari Majelis Tarjih PP Muhammadiyah), Hendro Sentyanto, M.Si, (astronom dari Lajnah Falakiyah PBNU), dan K.H. Mahyudin Junaedi, MA (dari MUI) (Tdjamaluddin, tdjamaluddin. wordpress.com, diakses pada 17 Nopember 2016).

Berbagai ide dikemukakan dalam kongres ini. Intinya, umat Islam memerlukan suatu penanggalan yang dipakai bersama untuk kepentingan umat Islam secara internasional. Dalam konferensi ini diusulkan dua konsep kalender Islam yang telah dikaji oleh Scientific
Committee, yaitu kalender Islam bizonal dan kalender Islam terpadu. Kalender Islam Bizonal digagas oleh Nidhal Guessoum dan Mohammad Syawkat Odeh. Prinsip Kalender Islam Bizonal adalah (a) dunia dibagi dua zona, yaitu zona barat dan zona timur, (b) awal bulan Qamariah dimulai di kedua zona itu pada hari berikutnya apabila konjungsi (tawalludul hilal) terjadi sebelum fajar di Makkah, dan (c) awal bulan kamariah dimulai pada hari berikutnya di zona barat dan ditunda sehari pada zona timur apabila konjungsi terjadi antara fajar di Makkah dan pukul 12.00 UT. Sementara itu, kalender Islam terpadu digagas oleh Jamaluddin Abdul Razik dengan tiga prinsip yang dikembangkan, yaitu prinsip hisab, prinsip transfer rukyat, dan penentuan permulaan hari (Susiknan Azhari, http:www.republika.co.id, diakses pada 13 Nopember 2016.).

Akhirnya, melalui pemungutan suara, mayoritas peserta memilih kalender terpadu 
yang berbasiskan perhitungan astronomis imkan rukyat dengan mengacu kepada peristiwa ïtima (konjungsi) dan menggunakan International Date Line (IDL) sebagai awal perhitungan hari (Majelis Tarjih dan Tajdid, tarjih.or.id/ kongres-kalenderturki-akhirnya-tetapkan-konsep-unifikatif, diakses pada 17Nopember 2016).

Adanya penyatuan kalender Islam internasional ini memberi banyak keuntungan bagi umat Islam. Perbedaan-perbedaan yang kadang-kadang bermetamorfosis menjadi gesekan antar sesama umat Islam bisa dihindarkan. Memang, selama ini yang terjadi adalah perbedaan dalam menentukan awal peribadatan umat Islam, seperti 1 Ramadhan dan 1 Syawal. Perbedaan ini timbul karena umat Islam yang menggunakan penanggalan melalui peredaran bulan (Qamariyah), sering tidak sependapat tentang cara menentukan awal masuknya bulan baru. Satu pihak menggunakan hisab, sedangkan pihak lain menggunakan rukyat. Dalam konteks keindonesiaan sendiri, perbedaan ini tidak jarang diposisikan secara bertentangan dan berlawanan. Masing-masing pihak menggunakan dalil untuk mendukung argumentasinya dan menolak argumentasi pihak lain. Sekarang, sejalan dengan tingkat pemahaman umat Islam yang semakin meningkat, perbedaan diametral tersebut sudah tidak dominan lagi dan diposisikan linear secara keilmuan (Arwin Juli Rakhmadi Butar-butar, 2015: 45).

Tentu saja hal di atas merupakan tren perkembangan yang positif. Ada upaya mencari titik temu di antara dua pendekatan hisab dan rukyat dalam penentuan kalender Islam. Dalam konteks Islam internasional, tren ini ditindaklanjuti dengan upaya penyatuan kalender Islam secara mendunia. Tulisan ini tidak akan mengkaji tentang penyatuan kalender Islam secara astronomis. Tulisan ini hanya ingin mendiskusikan bagaimana manfaat penyatuan kalender Islam internasional secara politis. Secara sistematis, tulisan ini akan berbicara tentang latar belakang historis kalender Islam, urgensi penyatuan kalender Islam internasional dan faktor-faktor yang memengaruhi terwujudnya kalender Islam internasional.

\section{LATAR BELAKANG HISTORIS}

Penanggalan Islam yang dihitung berdasarkan peristiwa hijrah Nabi Muhammad Saw dan para sahabat dari Makkah ke Madinah berbeda dengan penanggalan Masehi yang dihitung dari hari lahirnya Yesus Kristus. Penanggalan Islam menggunakan perhitungan peredaran bulan (Qamariyah, lunar) yang ditandai bulan sabit (hilâl). Perhitungan hari dimulai dengan terbenamnya matahari. Satu tahun qamariyah berjumlah 354,3672 hari selama dua belas kali bulan mengelilingi bumi, yaitu 29 hari 12 jam 44 menit 3 detik $(29,5306$ hari=1 bulan).

Sementara penanggalan Masehi menggunakan perhitungan kalender solar (Syamsiyah), yaitu berdasarkan, perhitunganperhitungan gerak matahariatau gerak bumi berevolusi terhadap matahari. Pergantian hari baru dimulai pada pukul 00.00. Tahun Syamsiyah dihitung berdasarkan lamanya bumi sekali beredar mengelilingi matahari, yakni 365 hari, 5 jam 48 menit, 46 detik atau dibulatkan menjadi 365 hari. Setelah ditetapkan bahwa tiap tahun terdiri atas 365 hari, tetapi setiap tahun kurang 366 hari, maka agar perhitungan tarikh ini tetap, setiap 4 tahun sekali ditambah dengan satu hari (pada bulan Februari). Tahun ini disebut tahun kabisat, yaitu tahun yang jumlah harinya 366 hari. Dari perbedaan ini, terdapat selisih sebelas hari dalam setahun antara kalender Hijriyah dan kalender Masehi.

Bagi umat Islam, sistem penanggalan qamariyah ini bukan hanya untuk kepentingankepentingan ekonomis, sosiologis atau budaya belaka. Lebih dari itu, sistem penanggalan ini memiliki urgensinya dalam masalah-masalah ibadah. Sebagian ibadah umat Islam sangat terkait dengan penanggalan. Ibadah-ibadah 
seperti puasa, zakat dan haji sangat terkait dengan akurasi penanggalan tahun Qamariyah.

Dalam praktiknya, selama ini umat Islam, jangankan antar-negara, di sebuah negara seperti Indonesia pun sering berbeda pendapat dalam masalah penetapan awal bulan yang berentet pula pada ibadah. Perbedaannya terletak pada metode penentuan awal bulan. Ada yang menggunakan metode rukyat, yaitu menentukan awal bulan dengan melihat hilal (bulan sabit) pada akhir bulan Qamariyah, khususnya bulan Sya ban, Ramadhan dan Zulqa'idah untuk menentukan tanggal satu. Pada sisi lain ada juga yang menggunakan metode hisab, yaitu penghitungan gerak faktual bulan dan matahari dengan untuk menentukan tanggal satu (Arwin Juli Rakhmadi Butar-butar, 2015:51-52).

\section{URGENSI}

Kenyataan inilah agaknya yang mendasari diadakannya Kongres Penyatuan Kalender Hijriah Internasional tersebut. Setidaknya ada beberapa hal yang menjadikan penyatuan ini urgen dan mendesak untuk dilakukan.

Pertama, mewujudkan persatuan dan kesatuan umat Islam. Dengan penyatuan ini persatuan dan kesatuan ini akan lebih mudah diwujudkan. Seluruh dunia Islam menyatu dalam satu penanggalan yang sama. Ini pada gilirannya akan membangun solidaritas umat (ukhuwah Islâmiyah) di dunia Islam. Umat Islam akan memiliki rasa bersaudara dan merasakan bahwa masalah yang dialami saudaranya di belahan bumi yang lain juga merupakan masalah mereka. Mereka akan membantu saudara mereka yang mengalami satu masalah.

Secara politis, kesatuan ini akan meningkatkan posisi tawar dunia Islam dalam pergaulan internasional. Penyatuan kalender Islam menjadi simbol kesatuan politik umat. Kalau masa lalu khilafah Islamiyah dianggap sebagai simbol kesatuan politik umat Islam, untuk masa sekarang agaknya khilafah tidak lagi relevan dan tidak memiliki urgensinya bagi kesatuan politik umat Islam. Apalagi dengan adanya sekat-sekat teritorial yang didasari nasionalisme, mengharapkan lahirnya khilafah Islamiyah agaknya mirip dengan mengimpikan gagak putih. Karena itu, penyatuan kalender Islam internasional ini diharapkan sebagai langkah awal bagi upaya penyatuan politik umat Islam.

Dengan penyatuan ini, diharapkan setidaknya dunia Islam memiliki sikap yang sama dalam merespons isu-isu internasional yang berkaitan dengan kepentingan politik umat Islam. Masalah-masalah Palestina, Irak, Suriah, Iran, Afghanistan, kaum minoritas Rohingya di Myanmar, Muslim Kashmir di India, Muslim Patani di Thailand selatan dan Muslim Mindanao di Philipina selatan serta di berbagai wilayah dunia lainnya dapat direspons dengan sikap yang sama. Dengan demikian, penyelesaian masalah-masalah tersebut akan lebih mudah dilakukan.

Bila terdapat sikap dan respons yang sama di dunia Islam dalam menanggapi masalahmasalah krusial terutama yang berikaitan dengan kepentingan umat Islam, maka dunia Islam akan mempunyai kekuatan politik yang berarti. Negara-negara besar akan berpikir panjang untuk menentukan langkah-langkah politik mereka berikaitan dengan isu-isu tersebut. Apabila terjadi suatu permasalahan yang menimpa umat Islam di satu negara, maka negara-negara Muslim lainnya akan segera membantu meringankan dan mengatasi masalah tersebut.

Kedua, mewujudkan kesatuan dalam waktu-waktu ibadah umat Islam. Adanya penyatuan kalender internasional Islam ini akan semakin memudahkan pelaksanaan ibadah umat Islam. Dengan penyatuan ini, dunia Islam sudah dapat menentukan jadwal-jadwal ibadah puasa, Idul Fitri, ataupun Idul Adha jauh hari sebelumnya. Ini akan memberikan kepastian 
adanya kebersamaan dan keseragaman umat Islam dalam melaksanakan ibadah maupun hari besarnya.

Kesamaan pelaksanaan ibadah ini akan memperkecil sekat-sekat perbedaan di kalangan umat Islam. Kalau diperhatikan, khususnya di Indonesia, umat Islam sering berbeda dalam menentukan awal Ramadhan dan awal Syawal, yang pada gilirannya akan berekses pada pembenaran sikap dan pendapat masing-masing dan penolakan atas sikap dan pandangan yang berbeda dengannya. Sebagai contoh, kelompok yang meyakini 1 Syawal jatuh pada hari Senin, misalnya, tentu akan menganggap bahwa saudaranya yang masih berpuasa pada hari itu sebagai tindakan keliru dan haram. Mereka berdosa, karena berpuasa pada hari yang dilarang dalam Islam. Sebaliknya, kelompok yang memandang 1 Syawal jatuh pada keesokan harinya menganggap saudaranya yang tidak berpuasa hari Senin juga berdosa, karena mereka meninggalkan kewajiban berpuasa dengan sengaja.

Apalagi sejalan dengan bergulirnya roda reformasi, semua orang berhak mengemukakan pendapatnya. Dengan beralasan pada kebebasan berbicara, maka semua pihak berhak mempertahankan pandangan dan pendapatnya.

Perbedaan ini, yang kalau tidak dapat dikelola dengan baik, tentu akan berakibat pada perselisihan. Tidak tertutup kemungkinan khatib shalat Idul Fitri ikut membahas masalah ini dalam khutbahnya. Kalau isi khutbahnya bersifat menenangkan tidak masalah, bahkan akan baik, karena memberikan pencerahan kepada umat. Namun, bila si khatib ikut memanas-manasi perbedaan dan mendukung satu pandangan serta mengecam pandangan yang lain, ini tentu tidak positif bagi sebagian besar umat Islam yang tidak terlalu memahami masalah tersebut.

Kalau dilakukan kilas balik, pemerintahan Orde Baru Soeharto agaknya berjasa dalam menyatukan pengamalan agama umat Islam. Dengan kekuasaannya, Presiden Soeharto melalui Menteri Agama ketika itu menetapkan penentuan awal Ramadhan maupun Syawal yang disepakati oleh semua unsur umat Islam. Jarang sekali ditemukan perbedaan hari raya umat Islam pada masa Soeharto. Kalau ada yang berbeda dengan kebijakan negara, itu tidak signifikan dan tidak dianggap mewakili kelompok umat Islam. Ketika itu pemerintahan Soeharto benar-benar mengamalkan kaidah hukm al-hâkim yarfa ul khilâf (Putusan negara menghilangkan perbedaan pendapat).

Ketiga, pada tingkat global, penyatuan ibadah ini juga menguntungkan bagi umat Islam yang berada di wilayah-wilayah mayoritas nonMuslim. Ketua Majelis Ulama Indonesia, KH. Muhyiddin Djunaedi, yang hadir dalam Kongres Kalender Islam Global di Turki, mengatakan bahwa dalam Kongres tersebut banyak peserta yang datang dari negara-negara minoritas Muslim, terutama dari negara-negara Barat seperti Amerika dan Eropa, menyampaikan keluhan mereka. Menurutnya, meskipun satu masjid, satu daerah, dan satu negara, ternyata mereka berbeda dalam penanggalan ini (Okezone News, news.okezone. com/read/ ... /eksklusif-umat-islam-dunia-harus-miliki kalender-tunggal, diakses pada 10 Nopember 2016). Dampak dari perbedaan dalam penanggalan dan ritual itu, lanjut Mahyudin, adalah umat Islam di sana tak diperhitungkan.

Misalnya untuk meminta hari Lebaran kepada pemerintah. Katakanlah tanggal 6, jangan-jangan nanti Idul Fitri-nya tanggal 7. Ini jadi masalah. Mereka harus menyewa bangunan dua hari (untuk ibadah) dengan mahal dan belum tentu juga pemerintah yang bersangkutan memberi izin dua hari karena minoritas."

Dengan penyatuan ini, umat Islam, khususnya di wilayah-wilayah yang mayoritas non-Muslim, memiliki kepastian penanggalan waktu-waktu ibadah mereka. Ini akan membuat mereka merasa tenang dan nyaman dalam beribadah. 


\section{FAKTOR-FAKTOR YANG MENDUKUNG TERWUJUDNYA KALENDER ISLAM INTERNASIONAL}

Mewujudkan kesatuan kalender Islam bukanlah masalah yang mudah semudah membalik telapak tangan. Banyak sekali faktor yang berpengaruh bagi terwujudnya penyatuan tersebut. Faktor-faktor ini agaknya perlu mendapatkan perhatian serius. Menurut Thomas Djamaluddin, Ketua Lembaga Penerbangan dan Antariksa Nasional (LAPAN), perlu diperhatikan beberapa faktor yang menjadi syarat untuk mewujudkan kalender Islam internasional ini. Pertama, adanya otoritas tunggal; $k e d u a$, adanya kriteria tunggal; dan ketiga adalah batas wilayah (Okezone News, http:// news.okezone. com, diakses pada 12 Nopember 2016).

Dalam faktor pertama, untuk konteks keindonesiaan, otoritas tersebut adalah pemerintah, dalam hal ini Kementerian Agama Republik Indonesia dan untuk tingkat internasional adalah Organisasi Kenferensi Islam (OKI).

Pemerintah harus memainkan peran siyasahnya sebagai "hakim" yang menghilangkan perbedaan-perbedaan pendapat dalam tataran yang prinsip. Pemerintah sekarang dalam hal ini agaknya perlu belajar banyak dari peerintahan Orde Baru Soeharto dalam menyatukan berbagai perbedaan ini. Pemerintah harus bisa merangkul semua elemen organisasi Islam dan mencarikan titik temu dari perbedaan-perbedaan yang ada. Harus ada solusi yang dapat disepakati bersama. Pada sisi lain, masing-masing organisasi Islam juga harus dapat menepis ego primordialnya dan bersedia menerima putusan yang telah disepakati bersama di bawah koordinasi negara. Ini tentu membutuhkan sikap kenegarawanan pemangku jabatan yang diamanahkan untuk menangani masalah ini dan juga sikap kebersamaan organisasi-organisasi Islam. Kalau hal ini dapat terwujud, maka mewujudkan kalender Islam internasional agaknya bukanlah sebuah mimpi.
Pada tingkat internasional, penyatuan ini memerlukan peranan Organisasi Konferensi Islam (OKI), karena OKI-lah yang dianggap sebagai pemersatu dan jembatan antara perbedaan-perbedaan yang ada. OKI harus berperan sebagai lembaga bangsa-bangsa Muslim sebagaimana yang pernah digagas Iqbal (1887-1938), Muhammad Iqbal adalah penyair pemikir India kelahiran Sialkot, Punjab, yang menjadi inspirator bagi berdirinya negara Pakistan. Ia berasal dari keturunan keluarga kasta Brahmana Kashmir yang telah memeluk Islam sejak tiga abad sebelum kelahirannya. Setelah menempuh pendidikan tradisional di India, Iqbal menempuh pendidikan ke Cambridge University, Inggris dan mendapatkan gelar doktornya di Munich University Jerman pada 1907, atau sebagaimana yang digagas lembaga ijma internasional seperti yang pernah dicetuskan Fazlurrahman (1919-1988).

Fazlurrahman adalah salah seorang tokoh pembaru Islam kontemporer asal Pakistan yang lahir 1919. Ia mengklaim dirinya sebagai tokoh Neo-modernisme Islam. Ketika berada di Pakistan ia sempat menjadi Direktur Institute Riset Islam Pakistan di Karachi, di bawah Presiden Jenderal Ayyub Khan. Karena pemikiran-pemikirannya banyak berseberangan dengan pemikiran ulama tradisional yang konservatif, maka akhirnya hengkang dari Pakistan dan hïrah ke Amerika Serikat. Di sini ia menjadi Guru Besar di University of Chicago dan dari sini pula ia menggemakan gagasan-gagasan Neomodernismenya.

Dalam karyanya The Reconstruction of Religious Thought in Islam, Iqbal menyatakan bahwa Islam bukanlah nasionalisme atau imperialisme, melainkan sebuah lembaga bangsa-bangsa yang mengakui batas-batas yang dibuat manusia dan perbedaan rasial, tetapi tidak untuk membatasi nuansa sosial umatnya (Muhammad Iqbal, 1981: 159). Sementara Fazlurrahman mengelaborasi gagasan Iqbal dengan mengembangkan konsep lembaga 
$174 \|$

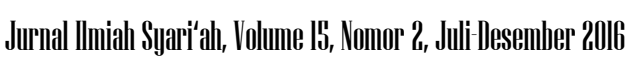

legislatif internasional yang anggotanya berasal dari perwakilan negara-negara Muslim (Fazlurahman, 1979: 261-262).

OKI memainkan perannya yang strategis dalam berbagai persoalan dunia Islam. Seperti telah jamak diketahui, di dunia Islam terdapat dua blok pemikiran dan politik Islam, yang kadang-kadang sulit dipertemukan, yaitu blok Sunni dan blok Syi i. Sejarah panjang dua aliran ini sebagian diisi oleh pertentangan dan peperangan. Warisan sejarah ini sampai sekarang pun masih dirasakan di kalangan umat Islam hingga hari ini. Belum lagi dalam konteks politik dua negara yang sering dianggap sebagai representasi dari dua kelompok aliran tersebut, Arab Saudi dan Iran, juga masih belum sepenuhnya mau bergandengan tangan.

Sampai hari ini, secara politik dunia Islam masih terseok-seok dipermainkan oleh kekuatan asing. Irak bergolak, Suriah terluka, Libya tercabik dan Palestina ternista oleh Israel yang didukung sepenuhnya oleh Amerika Serikat. Timur Tengah masih tetap membara dan belum terlihat tanda-tanda perkembangan positif. Sementara Iran juga "dikeroyok" oleh Amerika Serikat dan sekutu-sekutunya.

Pada sisi lain, perjalanan usaha penyatuan kalender Islam internasional ini ternyata sudah sangat panjang. Susiknan mencatat bahwa sejak tahun 1978 telah dilakukan upaya demikian melalui Kengres yang juga diadakan di Turki. Kongres ini menyepakati kaidah-kaidah penentuan awal bulan Qamariah dan pembentukan komisi penyusunan kalender Islam. Kaidah yang dimaksud adalah (1) pada dasarnya penetapan awal bulan dengan rukyat, (2) sah menentukan masuknya awal bulan dengan rukyat di salah satu tempat dan berlaku seluruh dunia, dan (3) sahnya penggunaan hisab dalam penetapan awal bulan Qamariah harus dipenuhi dua syarat, yaitu elongasi delapan derajat dan ketinggian hilal minimal lima derajat (Susiknan Azhari, http://www.republika.co.id, diakses pada 13 Nopember 2016).
Konferensi ini juga menyetujui 10 negara sebagai anggotanya bertugas melakukan perhitungan kalender untuk setiap dua tahun. Kesepuluh negara tersebut adalah Aljazair, Bangladesh, Indonesia, Irak, Qatar, Kuwait, Mesir, Saudi Arabia, Tunisia, dan Turki. Komisi ini telah melakukan sidang sebanyak tujuh kali, yaitu di Istanbul, Aljazair, Tunisia, Jeddah, dan Indonesia. Pertemuan-pertemuan tersebut menghasilkan kalender Hijriyah sampai 1411 H/1991. Pada pertemuan di Jakarta, 1987, disepakati pertemuan kedelapan akan dilaksanakan di Kuwait atau Irak pada 1989. Namun, sebelum tiba waktunya, meletus perang Irak-Kuwait, sehingga sidang kedelapan Komisi Penyusuan Kalender Islam Internasional ditunda dan belum bisa terwujud hingga kini (Susiknan Azhari, http://www.republika.co.id, diakses pada 13 Nopember 2016).

Dari perjalanan tersebut Kongres Turki tampaknya merupakan sebuah momentum bagi realisasi usaha tersebut. Mengingat situasi dan kondisi politik dunia Arab (Timur Tengah) yang tidak terlalu stabil, Indonesia sebenarnya bisa memainkan peran penting bagi usaha ini. Indonesia harus mengambil inisiatif untuk melakukan lobi-lobi terhadap negara yang mayoritas penduduknya Muslim. Dari sisi diplomatik, Indonesia relatif memiliki hubungan diplomatik yang relatif baik dengan negaranegara lain dunia Islam, sehingga tidak memiliki beban untuk melakukan diplomasi dan lobi-lobi. Dari sisi penduduk, tidak dapat dipungkiri bahwa Indonesia merupakan negara yang berpenduduk Muslim terbesar di dunia. Sementara dari sisi kondisi internal, Indonesia tidak memiliki masalah yang krusial di dala negeri. Riak-riak yang terjadi di dalam negeri saat ini dapat dikatakan hanya sebagai dinamika Indonesia saja sebagai negara demokratis.

Harapan ini sepertinya direspons oleh pemerintah Indonesia. Kementerian Agama (Kemenag) berharap Indonesia bisa menjadi tuan rumah konferensi untuk menentukan penyatuan 
penanggalan Islam atau kalender Hijriah international. Indonesia layak menjadi tuan rumah mengingat populasi muslim terbesar di dunia. Direktur Urusan Agama Islam Kemenag, Muhammad Tambrin, menyambut baik usaha ini. Dalam Diskusi Live Streaming Redbons bertajuk 'Menuju Penyatuan Penanggalan Islam Sedunia' di Kantor RedaksiOkezone, Gedung High-End, Jalan Kebon Sirih Raya, Jakarta Pusat, Rabu, 30 Juni 2016, Muhammad Tambrin menyatakan, "Kita menyambut baik. Kita juga menunggu Indonesia yang majemuk dan heterogen ini, kalau Turki bisa jadi tuan rumah kenapa Indonesia tidak bisa (Okezone News, http://news.okezone.com/read/2016/06/30/33 7/1429775/kemenag-dukung-indonesiajadi-pusat-penyatuan-penanggalan-islam-dunia, diakses 18 Nopember 2016)."

Ini tentunya merupakan sinyal dari pemerintah yang mendukung sepenuhnya upaya penyatuan penanggalan tersebut. Namun begitu, kerja ini bukanlah hal yang mudah. Indonesia harus mampu meyakinkan negaranegara Muslim lainnya untuk menepiskan ego masing-masing dan mengedepankan kepentingan bersama umat Islam. Karenanya, dibutuhkan dari Indonesia tokoh-tokoh mumpuni yang mampu melaksanakan kerja besar ini.

\section{PENUTUP}

Dari paparan di atas dapat disimpulkan bahwa penentuan kalender Islam internasional merupakan kebutuhan yang sangat mendesak untuk diwujudkan. Dari perspektif siyasah, adanya kalender Islam internasional akan memperlihatkan kepada dunia kekuatan dan kekompakan dunia Islam. Negara-negara Muslim dunia akan memiliki kesamaan sikap dan respons terhadap masalah-masalah global yang berkembang, terutama yang berkaitan dengan kepentingan politik umat Islam. Memang perkerjaan ini merupakan proyek besar yang membutuhkan waktu untuk mewujudkannya. Mengingat Indonesia merupakan negara Muslim terbesar yang relatif tidak terganggu oleh masalah-masalah politik internasional dan secara nasional juga relatif stabil, maka peranan Indonesia menjadi signifikan dalam upaya penyatuan ini.

\section{DAFTAR KEPUSTAKAAN}

Djamaluddin, Thomas. 2016. Berbagi ilmu untuk pencerahan dan Informasi, (online) (tdjamaluddin.wordpress.com https://www.tdjamaluddin.wordpress. com, diakses pada 17 Nopember 2016, pukul 08.50.

Azhari, Susiknan. 2016. Kalender Islam Global, (online), www.republika.co.id, Rabu, 2 Juni 2016, diunduh, 13 Nopember 2016.

Majelis Tarjih dan Tajdid. 31 Mei 2016. Kongres Kalender Turki Akhirnya Tetapkan Konsep Unifikatif, (online), tarjih.or.id/kongreskalender-turki-akhirnya-tetapkankonsep-unifikatif diakses pada 17 Nopember 2016, pukul 08.52.

Butar, Arwin Juli Rakhmadi Butar. 2015. EsaiEsai Astronomi Islam, Medan: UMSU Press.

Okezone News, 2016. Ini Syarat Penyatuan Penanggalan Islam Dunia, (online), news.okezone.com/read/.../eksklusifini-syarat-penyatuan-penanggalan-

Okezone News, 2016. Kemenag Dukung Indonesia Jadi Pusat Penyatuan Penanggalan Islam Dunia, (online), news.okezone. com/read/.../kemenag-dukung indonesia-jadi-pusat-penyatuanpenanggalan-islam-dunia, diunduh 18 Nopember 2016, pukul 11.03 WIB.islamdunia, diunduh 12 Nopember 2016, pukul 08.10 WIB. 
$176 \|$

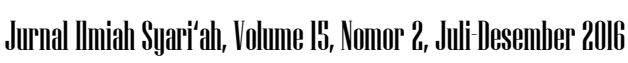

Okezone News, 2016. Umat Islam Dunia Harus Miliki Kalender Tunggal, (online) news.okezone.com/read/.../eksklusifumat-islam-dunia-harus-miliki-kalendertunggal, diunduh 10 Nopember 2016, pukul 07.30 WIB.
Iqbal, Muhammad. 1981. The Reconstruction of Religious Thought in Islam, Delhi: Kitab Bhavan.

Fazlurahman, 1979. Islam, Chicago dan London: University of Chicago Press. 